\title{
Mastication in children and adolescents with overweight or obesity: a systematic review
}

\author{
Mastigação em crianças e adolescentes \\ com sobrepeso ou obesidade: \\ uma revisão sistemática
}

\author{
Renata Emmanuele Assuncão SANTOS ${ }^{1}$ (D) 0000-0002-2166-3626 \\ Diego Cabral LACERDA 1 ID 0000-0002-1741-4707 \\ Maria Giselda da SILVA² ID 0000-0003-1529-0269 \\ Danielly Alves Mendes BARBOSA ${ }^{3}$ ID 0000-0003-4540-0334 \\ Isabeli Lins PINHEIRO4 (ID) 0000-0003-4624-1670 \\ Kelli Nogueira FERRAZ PEREIRA4 ID) 0000-0002-3180-0866
}

\section{A B S T R A C T}

Studies have shown that changes in mastication are related to overweight in children and adolescents as these changes influence the increase in food consumption. The objective of this article was to characterize, through a systematic review, the mastication in children and adolescents with overweight or obesity. For this, two independent authors performed a systematic review of the electronic databases: Medical Literature Analysis and Retrieval System Online, Scopus, Cumulative Index to Nursing and Allied Health, Web of Science and Latin American and Caribbean Literature in Health

1 Universidade Federal de Pernambuco, Centro de Ciências da Saúde, Programa de Pós-Graduação em Nutrição. Recife, PE, Brasil.

2 Universidade Federal de Pernambuco, Centro Acadêmico de Vitória, Programa de Pós-Graduação em Nutrição, Atividade Física e Plasticidade Fenotípica. Vitória de Santo Antão, PE, Brasil.

3 Universidade Federal de Pernambuco, Centro Acadêmico de Vitória, Departamento de Enfermagem. Vitória de Santo Antão, PE, Brasil.

${ }^{4}$ Universidade Federal de Pernambuco, Centro Acadêmico de Vitória, Departamento de Educação Física e Ciências do Esporte. R. Alto do Reservatório, s/n., Bela Vista, 55608-680, Vitória de Santo Antão, PE, Brasil. Correspondence to: K.N. FERRAZ PEREIRA. E-mail: <kelliferraz@hotmail.com>.

Article based on the dissertation by REA SANTOS, entitled "Desempenho mastigatório de crianças com sobrepeso e obesidade da Zona da Mata do estado de Pernambuco, Brasil". Universidade Federal de Pernambuco; 2019.

How to cite this article

Santos REA, Lacerda DC, Silva MG, Barbosa DAM, Pinheiro IL, Ferraz Pereira KL. Mastication in children and adolescents with overweight or obesity: a systematic review. Rev Nutr. 2021;34:e190201. https://doi.org/10.1590/1678-9865202134e190201 
Sciences. Masticatory characteristics were considered as primary outcomes; the methods of analyzing mastication, the physical characteristics of the foods/materials used in the analyses and the fasting time were considered as secondary outcomes. This review was prepared in accordance with the items of the preferential reports for systematic analysis and meta-analysis. The systematic review protocol was submitted to the International Prospective Registry of Systematic Reviews. Nine articles were included in this review. The reviewed articles suggest that children and/or adolescents with overweight or obese present masticatory damages because they have worse masticatory performance and altered orofacial myofunctional characteristics.

Keywords: Adolescent. Child. Mastication. Obesity. Stomatognathic system.

\section{RESUMO}

Estudos têm demonstrado que alterações na mastigação estão relacionadas ao excesso de peso em crianças e adolescentes, o que pode levar ao aumento do consumo alimentar. O objetivo deste artigo foi caracterizar, através de uma revisão sistemática, a mastigação em crianças e adolescentes com sobrepeso ou obesidade. Para isso, dois autores independentes realizaram uma revisão sistemática nas bases de dados eletrônicas Medical Literature Analysis and Retrieval System Online, Scopus, Cumulative Index to Nursing and Allied Health, Web of Science e Literatura Latino-Americana e do Caribe em Ciências da Saúde. As características mastigatórias foram consideradas desfechos primários; os métodos de análise da mastigação, as características físicas dos alimentos/materiais utilizados nas análises e o tempo de jejum foram classificados como desfechos secundários. Esta revisão foi elaborada de acordo com os itens dos relatórios preferenciais para análise sistemática e metanálises. O protocolo de revisão sistemática foi submetido ao Registro Internacional Prospectivo de Revisões Sistemáticas. Nove artigos foram incluídos nesta revisão. Os resultados dos artigos revisados sugerem que crianças elou adolescentes com sobrepeso ou obesidade apresentam danos mastigatórios, pois possuem pior performance mastigatória e características miofuncionais orofaciais alteradas.

Palavras-chave: Adolescente. Criança. Mastigação. Obesidade. Sistema estomatognático.

\section{NTRODUCTION}

Overweight and obesity are defined as abnormal or excessive fat accumulation leading to health risk [1]. These conditions are present in different age groups, such as in childhood and adolescence, both critical periods of development characterized by high neural plasticity $[2,3]$. The percentage of children and adolescents aged between 5 and 19 years with these conditions has increased in recent years and by 2016 approximately 213 million were overweight and 124 million were considered obese [4]. In Brazil, 26.6\% of girls and $30 \%$ of boys 5 to 19 years old are overweight [4]. Obesity in childhood and adolescence is also common in Brazil, where $14.1 \%$ of children and $8.4 \%$ of adolescents are affected $[5,6]$. In addition, overweight and obesity have multifactorial consequences due to the association between genetic, metabolic, social, cultural and behavioral factors [7]. Among the metabolic and behavioral factors is the masticatory function. Studies have shown that changes in mastication are related to overweight/obesity, because these changes influence an increase in the food consumption of individuals [8].

The masticatory function (mastication) consists of the first stage of digestion and is responsible for breaking up food into smaller particles, suitable for the gastrointestinal absorption of nutrients [9]. It is a fundamental process in the cephalic phase of eating behavior, and the sensory stimulation triggered by the contact of food with the oral cavity promotes the release of appetite hormones, such as insulin and ghrelin [10]. Ferster et al. [8] proposed the hypothesis of a specific mastication style in individuals with obesity, with larger bites and shorter meal time, which would be related to an increase in food consumption. In healthy organisms, mastication increases the activation of histaminergic neurons in the paraventricular and ventromedial nucleus of the hypothalamus [11]. The higher activation of these neurons has been reported to be related to the decrease in food intake in rats [12]. 
Previous research has shown that high Body Mass Index (BMI) in children is associated with inadequate processing of a chewable material (Optocal) [13]. Children with a higher degree of obesity presented shorter meal time and masticatory cycles [14]. In addition, children and adolescents with obesity present important alterations in the orofacial myofunctional aspects of mastication [15]. Thus, the literature shows that foods eaten quickly with insufficient mastication are associated with reduced levels of orosensory signaling during feeding, leading to inadequate cephalic responses and late satiety [16]. This suggests that in children and adolescents with overweight or obesity, masticatory dysfunction may lead to increased food intake.

Due to the higher prevalence of overweight and obesity in childhood and adolescence, is relevant to understanding the mastication function as a factor that can affect the satiety, choice of food consistence and weight gain, being an important strategy to improve obesity characters. In view of the above, the present study aimed to characterize, through a systematic review, the mastication in children and adolescents with overweight or obesity. The masticatory characteristics, methods of evaluation of mastication, physical properties of food/materials used in the analyses and the fasting time of individuals is discussed. Our hypothesis is that children and adolescents with overweight or obesity present disfunctions on mastication parameters, which can affect food intake.

\section{METHODS}

This systematic review was elaborated according to the items of the preferential reports for systematic analysis and meta-analysis (PRISMA) [17]. In addition, the protocol of this systematic review was submitted to the International Prospective Registry of Systematic Reviews (Prospero) (Registration number: CRD 42017075339).

The bibliographic research was conducted in May 2019 using the electronic databases Medical Literature Analysis and Retrieval System Online (Medline/PubMed), Scopus, Cumulative Index to Nursing and Allied Health (CINAHL), Web of Science and Latin American and Caribbean Literature in Health Sciences (LILACS). The research was based on cross-sectional studies that analysed the mastication of children and adolescents with overweight and obesity. The following Medical Subject Headings (MeSH) terms or Descritores em Ciências da Saúde (DeCS) descriptors were included in the study: child, adolescent obesity, overweight, pediatric obesity, mastication, stomatognathic system, bite force and efficiency. There was no restriction on the year or language of publication.

The search in the electronic databases was performed by two independent reviewers and was based on a pre-defined protocol. A third reviewer was consulted when necessary and acted as mediator in the definition of the inclusion or exclusion criteria when there was no agreement between the reviewers. The data extraction was performed according to the evaluation of the eligibility criteria defined in the study. This review includes cross-sectional studies that evaluated the mastication of children and adolescents with overweight or obesity. The following exclusion criteria were used in this review: (i) studies that did not explain in detail the methodology used and (ii) randomized clinical trials.

The risk assessment of bias in the studies was independently performed by two reviewers using the Modified Health Care Research and Quality Agency (AHRQ) instrument. Cross-sectional studies were evaluated using a list of twenty-six items divided into nine evaluation criteria: study question, study population, subject comparability, exposure or intervention, measured outcomes, statistical analysis, results, discussion and funding, or sponsorship [18].

The primary outcomes of the literature review on mastication of children and adolescents with overweight or obesity include masticatory characteristics, taking into account bite force, food/material processing, number of masticatory sequences, number of masticatory cycles, meal rate, orofacial 
myofunctional characteristics and the electromyographic activity of the masticatory muscles. Secondary outcomes include the types of mastication analysis method, the physical characteristics of the foods/ materials used in the analyses, and the fasting time.

The levels of agreement between the reviewers and the quality of the studies (risk of bias) were analysed by the Kappa statistic using the Statistical Package for the Social Sciences SPSS, version 20 for Windows (IBM SPSS Software, Armonk, NY, USA).

\section{R E S U L T S}

The initial search in the databases identified 370 articles in Medline/PubMed, 100 articles in Scopus, 5 articles in CINAHL, 7 articles in the Web of Science and 21 articles in LILACS. After analysing the titles and abstracts of all 503 articles, 438 were excluded because they did not meet the inclusion criteria and/or met the exclusion criteria. After completing the evaluation of the remaining 65 articles, we found that 53 were duplicated and 3 did not meet the inclusion criteria and/or fulfilled the exclusion criteria after reading the texts completely. Thus, 9 articles were included in this review (Figure 1).

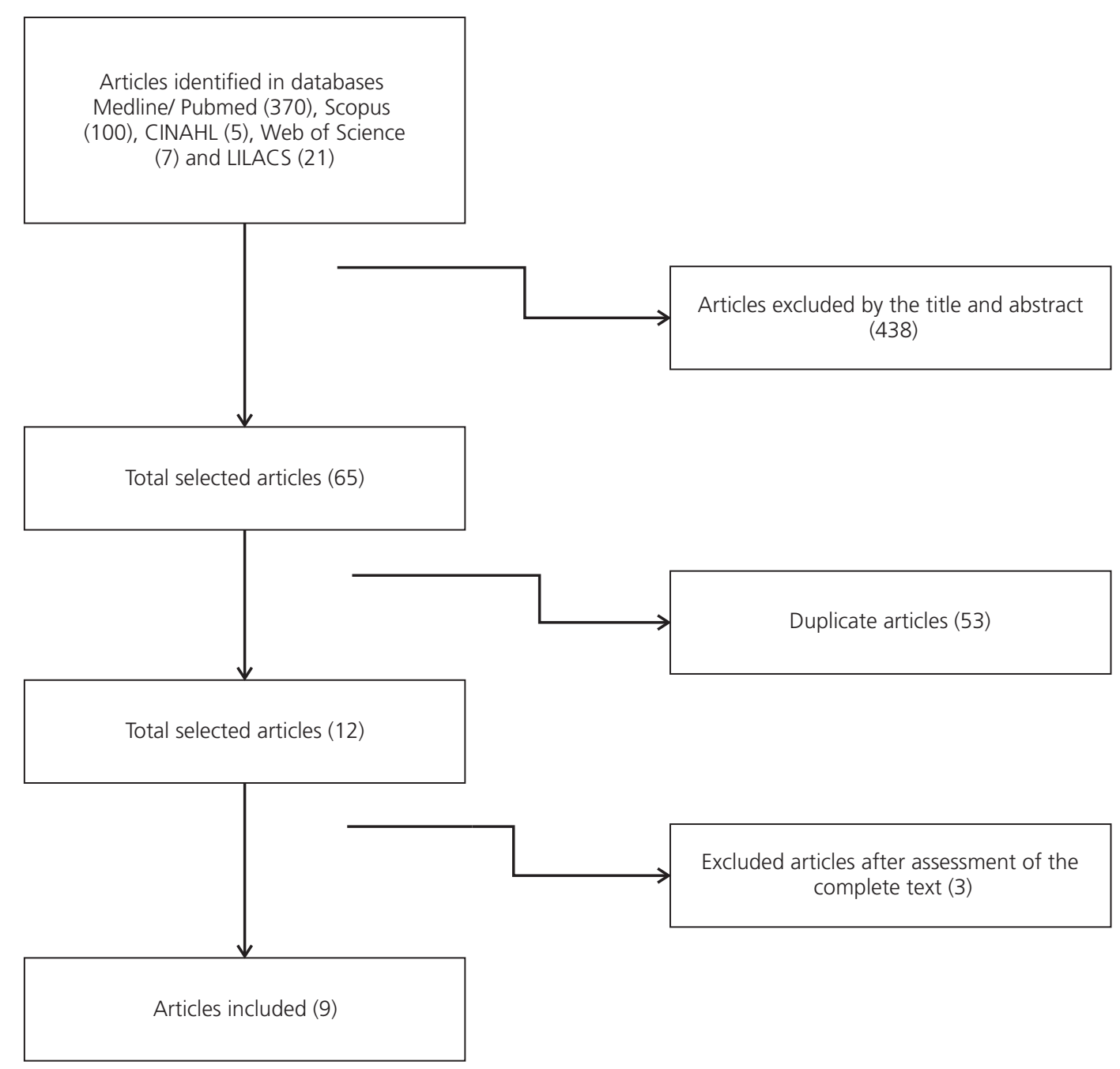

Figure 1 - Scheme of stages of selection of articles. 
Table 1 shows the evaluation of the articles according to the points highlighted by West et al. [18]. After evaluating the quality criteria, we observed that some studies showed methodological deficits, since: did not justify the sample size $[14,19,20]$; they do not have a comparison group [19]; did not use a validated instrument in the subjective analysis of mastication [14]; and did not mention sources of financing, even when they did not exist [20]. The level of agreement between reviewers for data extraction and bias risk analysis presented almost perfect agreement (Kappa: 0.8518) [21].

Table 1 - Characterization of the studies according to the evaluation criteria highlighted by West et al.

\begin{tabular}{|c|c|c|c|c|c|c|c|c|c|}
\hline \multirow[b]{2}{*}{ Author } & \multicolumn{9}{|c|}{ Domains } \\
\hline & $\begin{array}{c}\text { Study } \\
\text { Question }\end{array}$ & $\begin{array}{c}\text { Study } \\
\text { Population }\end{array}$ & $\begin{array}{l}\text { Comparability } \\
\text { of Subjects }\end{array}$ & $\begin{array}{c}\text { Exposure/ } \\
\text { Intervention }\end{array}$ & $\begin{array}{l}\text { Outcome } \\
\text { Measure }\end{array}$ & $\begin{array}{c}\text { Statistical } \\
\text { Analysis }\end{array}$ & Results & Discussion & Funding \\
\hline \multicolumn{10}{|l|}{$\begin{array}{l}\text { Pedroni-Pereira } \\
\text { et al. [15] }\end{array}$} \\
\hline \multicolumn{10}{|l|}{ Sun et al. [24] } \\
\hline \multicolumn{10}{|l|}{ Berlese et al. [19] } \\
\hline \multicolumn{10}{|l|}{ Araujo et al. [22] } \\
\hline \multicolumn{10}{|l|}{ Soares et al. [23] } \\
\hline \multicolumn{10}{|l|}{ Soares et al. [13] } \\
\hline \multicolumn{10}{|l|}{$\begin{array}{l}\text { Souza \& Guedes } \\
\text { [20] }\end{array}$} \\
\hline \multicolumn{10}{|l|}{$\begin{array}{l}\text { Sato \& Yoshiike } \\
\text { [14] }\end{array}$} \\
\hline $\begin{array}{l}\text { De Morais Tureli } \\
\text { et al. [25] }\end{array}$ & & & & & & & & & \\
\hline
\end{tabular}

Note:

Yes; : Partial; $\mathbf{O}$ : No information. Kappa: 0.8518

The results of the studies on masticatory characteristics, types of methods employed, food/materials used, and fasting time are summarized in Table 2. The studies evaluated different parameters of mastication and, for that, they used different methods, each one with its specificity. The nine studies reviewed $(n=9)$ used quantitative methods to analyze the mastication of children and adolescents with overweight or obesity $[13-15,19,20,22-25]$. Additionally, four $(n=4)$ of the nine articles also used qualitative methods to analyze chewing behavior $[14,15,22,23]$.

When assessing masticatory behavior, one study found that overweight/obese girls need to add liquid to better swallow food and consume fruit in small pieces $[14,15,22,23]$. Two studies $(n=2)$ found that children and adolescents with higher BMI did not present differences in consistency of food intake when compared to children and adolescents with normal BMI $[22,23]$. Finally, a study $(n=1)$ found that children with a higher degree of obesity took longer to swallow food and swallowed without chewing correctly [14].

When evaluating bite force $(n=4)$, two studies $(n=2)$ did not report differences between children and adolescents eutrophics, and with overweight and/or obesity $[14,15,22,23]$; one study $(n=1)$ found that girls with obesity and overweight boys had higher bite force when compared to eutrophic adolescents [24]; in contrast, another study $(n=1)$ found that children with higher BMI had lower bite force [22]. In the analysis of masticatory performance $(n=4)[14,15,22,23]$; three studies $(n=3)$ found that the higher the BMI 
Table 2 - Characterization of studies that analysed the mastication of children and adolescents with overweight or obesity. Vitória de Santo Antão (PE) Brazil, 2019.

1 of 2

\begin{tabular}{|c|c|c|c|c|c|}
\hline Author & $\mathrm{n}$ & $\begin{array}{c}\text { Age } \\
\text { (years) }\end{array}$ & $\begin{array}{c}\text { Methods of mastication } \\
\text { analysis }\end{array}$ & Parameters analysed & Results \\
\hline $\begin{array}{l}\text { Pedroni-Pereira } \\
\text { et al. [15] }\end{array}$ & 231 & 14 to 17 & $\begin{array}{l}\text { - Qualitative evaluation of } \\
\text { mastication/Questionnaire } \\
\text { "Quality of Masticatory } \\
\text { Function" } \\
\text { - Orofacial myofunctional } \\
\text { evaluation. } \\
\text { - Evaluation of masticatory } \\
\text { performance } \\
\text { - Bite Force Assessment } \\
\text { - Oral Clinical Evaluation }\end{array}$ & $\begin{array}{l}\text { - Food Consistency and eating } \\
\text { - Habits } \\
\text { - Color change in a chewing gum } \\
\text { - Maximum bite force } \\
\text { - Protocol OMES-e, domain } \\
\text { "mastication" } \\
\text { - Presence of dental caries and } \\
\text { malocclusion. }\end{array}$ & $\begin{array}{l}\text { Girls with overweight/obesity } \\
\text { (compared to normal weight } \\
\text { girls): } \\
\text { - Need to add liquid to food and } \\
\text { consumption of fruit in small } \\
\text { pieces. } \\
\text { - Unilateral mastication. } \\
\text { Girls and boys with overweight/ } \\
\text { obesity (compared to normal } \\
\text { weight boys and girls): } \\
\text { - There were no changes in } \\
\text { masticatory performance. } \\
\text { - They did not show differences } \\
\text { in maximum bite force. } \\
\text { - There were no differences } \\
\text { related to the presence of } \\
\text { dental caries and malocclusion. }\end{array}$ \\
\hline $\begin{array}{l}\text { Araujo et al. } \\
{[22]}\end{array}$ & 204 & 8 to 10 & $\begin{array}{l}\text { - Qualitative evaluation of } \\
\text { mastication/Questionnaire } \\
\text { "Food Type Verification } \\
\text { Protocol" } \\
\text { - Bite Force Assessment } \\
\text { - Oral Clinical Evaluation }\end{array}$ & $\begin{array}{l}\text { - Food Consistency and eating } \\
\text { Habits } \\
\text { - Maximum bite force } \\
\text { - Presence of dental caries and } \\
\text { malocclusion }\end{array}$ & $\begin{array}{l}\text { Girls and boys with overweight } \\
\text { and with obesity (compared to } \\
\text { eutrophic boys and girls): } \\
\text { - There were no changes in } \\
\text { the consistency of the food } \\
\text { consumed. } \\
\text { Girls and boys with higher BMl } \\
\text { (through a correlation test). } \\
\text { Less bite force. } \\
\text { - Greater need for orthodontic } \\
\text { treatment. }\end{array}$ \\
\hline $\begin{array}{l}\text { Soares et al. } \\
\text { [23] }\end{array}$ & 279 & 3 to 5 & $\begin{array}{l}\text { - Qualitative evaluation of } \\
\text { mastication/Food Registry } \\
\text { for three days } \\
\text { - Evaluation of masticatory } \\
\text { performance } \\
\text { - Oral Clinical Evaluation }\end{array}$ & $\begin{array}{l}\text { - Food Consistency } \\
\text { - Median particle size (X50) of a } \\
\text { chewable material for masticatory } \\
\text { function tests (Optocal) } \\
\text { - Presence of cavitated teeth and } \\
\text { malocclusion }\end{array}$ & $\begin{array}{l}\text { Girls and boys with higher BMI } \\
\text { (through a regression test): } \\
\text { - Those who consumed more } \\
\text { liquid foods presented worse } \\
\text { masticatory performance. } \\
\text { - Larger median food particle } \\
\text { size (X50) expelled after twenty } \\
\text { masticatory cycles. } \\
\text { - Greater number of cavitated } \\
\text { teeth (both anterior and } \\
\text { posterior) }\end{array}$ \\
\hline $\begin{array}{l}\text { Sato \& Yoshiiken } \\
\text { [14] }\end{array}$ & 61 & 5 to 6 & $\begin{array}{l}\text { - Qualitative evaluation of } \\
\text { mastication/Questionnaire } \\
\text { formulated by the authors } \\
\text { - Evaluation of masticatory } \\
\text { performance } \\
\text { - Bite Force Assessment } \\
\text { - Oral Clinical Evaluation }\end{array}$ & $\begin{array}{l}\text { - Eating Habits } \\
\text { - Number of masticatory cycles, } \\
\text { meal time and masticatory } \\
\text { frequency } \\
\text { - Maximum bite force } \\
\text { - Presence of dental caries and } \\
\text { malocclusion }\end{array}$ & $\begin{array}{l}\text { Girls and boys with higher } \\
\text { degree of obesity (through a } \\
\text { correlation test): } \\
\text { - They spent more time } \\
\text { swallowing food and } \\
\text { swallowing without chewing } \\
\text { properly. } \\
\text { - Less meal time and fewer } \\
\text { masticatory cycles. } \\
\text { - No changes were observed in } \\
\text { the occlusion force. } \\
\text { - There were no differences } \\
\text { related to the presence of } \\
\text { dental caries and malocclusion. }\end{array}$ \\
\hline
\end{tabular}


Table 2 - Characterization of studies that analysed the mastication of children and adolescents with overweight or obesity. Vitória de Santo Antão (PE) Brazil, 2019.

2 of 2

\begin{tabular}{|c|c|c|c|c|c|}
\hline Author & $\mathrm{n}$ & $\begin{array}{c}\text { Age } \\
\text { (years) }\end{array}$ & $\begin{array}{c}\text { Methods of mastication } \\
\text { analysis }\end{array}$ & Parameters analysed & Results \\
\hline Sun et al. [24] & 577 & 13 to 16 & - Bite Force Assessment & - Maximum bite force & $\begin{array}{l}\text { Girls with obesity: } \\
\text { - Higher bite force than } \\
\text { underweight and normal weight } \\
\text { girls } \\
\text { Overweight Boys: } \\
\text { - Higher bite force than } \\
\text { underweight, normal weight } \\
\text { and obesity boys }\end{array}$ \\
\hline $\begin{array}{l}\text { Berlese et al. } \\
\text { [19] }\end{array}$ & 28 & 8 to 16 & $\begin{array}{l}\text { - Orofacial myofunctional } \\
\text { evaluation } \\
\text { - Electromyographic } \\
\text { evaluation }\end{array}$ & $\begin{array}{l}\text { - Protocol OMES - All domains } \\
\text { - Electromyographic activity of } \\
\text { the masseter and temporal } \\
\text { muscles }\end{array}$ & $\begin{array}{l}\text { Girls and boys with obesity } \\
\text { (Compared to each other): } \\
\text { - Orofacial myofunctional } \\
\text { characteristics within normality } \\
\text { - There was no difference in } \\
\text { the mean electric activity of the } \\
\text { muscles during rest, mastication, } \\
\text { and swallowing }\end{array}$ \\
\hline $\begin{array}{l}\text { Soares et al. } \\
\text { [13] }\end{array}$ & 285 & 3 to 5 & $\begin{array}{l}\text { - Evaluation of masticatory } \\
\text { performance } \\
\text { - Evaluation of the } \\
\text { deglutition threshold } \\
\text { - Oral Clinical Evaluation }\end{array}$ & $\begin{array}{l}\text { - Median particle size (X50) of a } \\
\text { chewable material for masticatory } \\
\text { function tests (Optocal) } \\
\text { - Median particle size (X50) } \\
\text { expelled before the desire to } \\
\text { swallow the chewable material } \\
\text { (Optocal) } \\
\text { - Presence of dental caries and } \\
\text { malocclusion }\end{array}$ & $\begin{array}{l}\text { Girls and boys with higher BMI } \\
\text { (through a regression test): } \\
\text { - Larger median food particle } \\
\text { size (X50) expelled after twenty } \\
\text { masticatory cycles } \\
\text { - Larger median food particle } \\
\text { size (X50) during the evaluation } \\
\text { of the swallowing threshold } \\
\text { Girls and boys with lower BMI } \\
\text { (through a regression test): } \\
\text { - Less amount of dental caries }\end{array}$ \\
\hline $\begin{array}{l}\text { Souza \& } \\
\text { Guedes [20] }\end{array}$ & 50 & 9 to 18 & $\begin{array}{l}\text { - Orofacial myofunctional } \\
\text { evaluation }\end{array}$ & - Protocol OMES-e - All domains & $\begin{array}{l}\text { Girls and boys with obesity } \\
\text { (compared to eutrophic boys } \\
\text { and girls): } \\
\text { - Worse performance in the } \\
\text { aspects of tonicity and mobility } \\
\text { of the cheeks }\end{array}$ \\
\hline $\begin{array}{l}\text { De Morais Tureli } \\
\text { et al. [25] }\end{array}$ & 97 & 8 to 12 & $\begin{array}{l}\text { - Evaluation of masticatory } \\
\text { performance }\end{array}$ & $\begin{array}{l}\text { - Median particle size (X50) of a } \\
\text { chewable material for masticatory } \\
\text { function tests (Optocal) }\end{array}$ & $\begin{array}{l}\text { Girls and boys with overweight/ } \\
\text { obesity (compared to boys and } \\
\text { girls with normal weight and } \\
\text { underweight): } \\
\text { - Larger median food particle } \\
\text { size (X50) expelled after twenty } \\
\text { masticatory cycles }\end{array}$ \\
\hline
\end{tabular}

Note: BMI: Body Mass Index; OMES-e: Orofacial Myofunctional Assessment Protocol with Expanded Scores.

in children, the larger the particle size of a chewable material expelled orally after a series of masticatory sequences $[13,23,25]$; one study $(n=1)$ found that children with a high degree of obesity performed fewer masticatory cycles and ate faster [14]. In the analysis of orofacial myofunctional characteristics $(n=3)$, the literature shows that children and adolescents with obesity, when compared to eutrophic, present less tonicity of cheek muscles, and that female adolescents with overweight and obesity have a higher frequency of unilateral mastication $[15,19,20]$. In contrast, one study $(n=1)$ found that children and adolescents with 
obesity presented normal orofacial myofunctional characteristics, however, this study did not compare these results with an eutrophic control group, but did only a descriptive analysis of the data [19].

Among the studies that carried out qualitative analysis, two $(n=2)$ used validated questionnaires that evaluated masticatory quality through the analysis of consistency and eating habits $[14,15,22,23]$; one study $(n=1)$ used a three-day food record to analyze the consistency of the foods consumed [23]; and one study $(n=1)$ applied a questionnaire formulated by the authors, which had not been validated, to evaluate eating habits [14].

Among quantitative methods, the following techniques were applied: bite force analysis $(n=4)$ (using portable occlusal force meters) [14,15,22,24]; electromyographic analysis $(n=1)$ [19]; evaluation of masticatory performance $(n=5)$ (through specific techniques such as colorimetric analysis of a chewing gum, particle size of an chewable material orally expelled, and masticatory cycles and time taken during consumption of a meal) $[13-15,23,25]$, and orofacial myofunctional evaluation ( $n=3)$, using the Orofacial Myofunctional Assessment Protocol (OMES) and Orofacial Myofunctional Assessment Protocol with Expanded Scores (OMES-e) $[15,19,20]$. None of the studies controlled the subjects' fasting time before analysing mastication.

Regarding the type of food/material used in the analyses, we observed differences according to the methods used. In the analysis of masticatory performance, one study $(n=1)$ used a chewing gum that changes its color according to the time of chewing; three studies $(n=3)$ analysed the mean particle size of a chewable material, expelled after a series of mastication and/or desire to swallow, and one study $(n=1)$ that analysed mastication by offering a standard meal containing foods commonly consumed by individuals $[13-15,23,25]$. In the orofacial myofunctional evaluation, two studies used a stuffed cookie, and one study analyzed mastication through the consumption of a piece of bread $[15,19,20]$.

\section{DISCUSSION}

This study, aiming to characterize, through a systematic review, the mastication in children and adolescents with overweight and obesity, found in its synthesis and evaluation of the collected articles that children and/or adolescents with overweight or obesity presented impairment in masticatory performance and orofacial myofunctional characteristics. This was because they processed chewable material in larger sizes, ate faster, performed fewer masticatory cycles, as well as having less cheek muscle tone and, more often, unilateral mastication.

According to the risk of bias analysis tool (AHRQ, Agency For Healthcare Research And Quality), we observed that the reviewed articles were efficient in relation to the proposed study question [18]. However, some of them showed methodological deficit, mainly in the "Study Population" (description of the study population and justification of the sample size). Most research controlled the homogeneity of study groups by analyzing the presence of dental caries, dental occlusion and the respiratory characteristics of the subjects [13-15,20,22-25]. We also observed that the analysed studies showed heterogeneity in the methods of mastication analysis, in the foods/materials used and in the masticatory parameters evaluated. These differences made it impossible to apply a meta-analysis.

In the qualitative analysis of masticatory quality, two studies found changes in children and adolescents with overweight and obesity $[14,15]$. Children with obesity take longer to swallow a food and swallow without chewing properly [14]. Female teens with overweight and obesity need to add liquid to swallow a food better and consume fruit cut into small pieces [15]. It is evidenced in the literature that individuals with deficiencies in masticatory function tend to alter their diet to avoid foods that are more difficult to chew 
[26]. This may result in imbalance in food intake, with preferential consumption of soft and easily chewable foods such as highly processed foods, rather than those high in fiber and nutrients [13]. It is known that consumption of tougher foods to chew, such as high-fiber foods, leads to a lower overall food intake, compared to softer foods. This seems to occur because of its effect on the characteristics of oral processing [27]. In this context, we observed that children and adolescents with overweight or obesity with impairment of this function are known to alter their individual behaviors in order to facilitate mastication, increasing the consumption of more chewable foods, which are related to a higher caloric intake.

In evaluating the studies that analysed the bite force, we found contradictions among the results, since two studies $(n=2)$ did not report differences between eutrophic children and adolescents, and overweight and / or obesity $[14,15,22,24]$; one study $(n=1)$ found that girls with obesity and boys with overweight had greater bite strength when compared to eutrophic adolescents [24]; another study $(n=1)$ found that a higher BMI in children is associated with a lower bite force, although the model used in the study explains only $17.2 \%$ of this variation [22]. Bite force is an important indicator of the functional status of mastication [28]. It corresponds to the force exerted by the masticatory muscles to break down food and varies according to oral health, facial morphology, age and sex [29]. According to the literature, bite force is thought to be related to the integrity of the masticatory muscles; a greater bite force would result in a more efficient mastication [30]. Research has shown that individuals with obesity may present damage in the stomatognathic system due to the accumulation of adipose tissue in the region of the oral cavity, which can compromise the masticatory force [31]. In addition, impaired masticatory performance due to decreased bite force may result in imbalanced nutritional intake [24]. Since the few results were divergent, more research involving the analysis of the bite force of children and adolescents with overweight and obesity is necessary.

Most of the studies found that children and/or adolescents with overweight/obesity presented impairments in masticatory performance, since children with higher BMI processed a chewable material (Optocal) in larger sizes $[13,23,25]$. Children with these conditions consume a lot of foods rich in saturated fat, which are usually easy to chew. Therefore, it is believed that their masticatory muscles are not adequately stimulated to break down more consistent foods, such as the chewable material used in the studies reviewed [25]. Sato \& Yoshiike [14] observed that children with a higher degree of obesity performed fewer masticatory cycles and ate faster. A higher number of masticatory cycles before swallowing is associated with a lower risk of increased body weight in adults aged 35-61 years [32]. In addition, it is also known that adult women who eat faster take longer to feel satisfied with the amount of food ingested, which may contribute to the intake of more food, favoring an increase in BMI [33].

Two studies have also found alterations in the orofacial myofunctional characteristics of children and/or adolescents with overweight/obesity, evidenced in the lower tone of the cheek, although there were no differences during mastication, and unilateral mastication $[15,20]$. Orofacial myofunctional evaluation provides a comprehensive analysis of the components of the stomatognathic system in terms of appearance/posture, mobility and functional performance [34]. According to Strózyk \& Bałchanowski [35], changes in the stomatognathic system may have a negative impact on muscular forces, and oral functions, including masticatory function. Reduction of muscle tonus in the phonoarticulatory organs reduce the efficiency of masticatory movements, impairing mastication [36]. This can influence the choice of foods, seeking those that are easier to chew. In contrast, the consistency of the foods consumed over the long term can also cause damage to structures of the stomatognathic system, since it is believed that the masticatory load, which is the response to variations in the hardness, tenacity and particle size of the food, produces changes in craniofacial structures [37]. 
We also observed a great heterogeneity in relation to the food/materials used in the masticatory analysis, where four studies used chewable materials and four used natural food in their evaluations [13$15,19,20,23,25]$. We must consider that most studied objects in oral processing are mostly emulsions and model gels. These may not comprehensively describe the physical and chemical changes of foods like meat, fruit and vegetables, among others [38]. In contrast, some authors considered the artificial test materials preferable to natural foods because their physical properties are more reproducible and do not suffer from seasonal texture variation [39]. It is also known that the types of food used in masticatory analyses have a significant effect in parameters such as jaw movement, muscle activity and chewing rate [40]. This seems to occur due to the existence of a mechanism regulating the masticatory force that uses periodontal receptors to modify the strength and the number of masticatory cycles according to the physical characteristics of the food [41].

Although none of the studies reviewed controlled the individuals' fasting time, it is known that fasting can cause changes in mastication since, under normal conditions, food is ingested after the perception of hunger and intake ends when sensation satiety is reached [42]. Thus, in situations of fasting and satiety, the individual tends to behave differently, with exacerbated food reflexes $[41,42]$.

In addition, the absence of longitudinal studies that evaluate the relationship between mastication and overweight/obesity in children and adolescents makes it impossible to establish a cause-and-effect relationship. Thus, it was not possible to evaluate whether it was the changes in mastication by the children and adolescents studied that predisposed them to overweight/obesity, or if the overweight/obesity that caused changes in their mastication.

\section{CONCLUSION}

We observed that the articles suggest that children and/or adolescents with overweight or obesity present damages in mastication, showing in the lower masticatory performance and altered orofacial myofunctional characteristics. In function of the importance of mastication as a complementary factor, needs to be analyzed in clinical practice to understanding the overweight or obesity in childhood and adolescence.

\section{ACKNOWLEDGMENTS}

This study was supported by the Coordenação de Aperfeiçoamento de Pessoal de Nivel Superior (Capes, Coordination of Superior Level Staff Improvement) and Fundação de Amparo a Ciência e Tecnologia de Pernambuco (FACEPE, Foundation of Support to Science and Technology of Pernambuco).

\section{CONTRIBUTORS}

REA SANTOS, IL PINHEIRO, and KN FERRAZ PEREIRA contributed substantially to the conception and design of the study. REA SANTOS and DC LACERDA contributed to analysis and interpretation of data. REA SANTOS, MG SILVA, DAM BARBOSA, and KN FERRAZ PEREIRA contributed to writing of the manuscript. All authors approved the final submitted version.

\section{REFERE N CES}

1. World Health Organization. Obesity: preventing and managing the global epidemic: report of a WHO consultation. Geneva: Organization; 2000. 
2. Mundkur N. Neuroplasticity in children. Indian J Pediatr. 2005;72(10):855-7. https://doi.org/10.1007/BF02731115

3. Fuhrmann D, Knoll LJ, Blakemore SJ. Adolescence as a sensitive period of brain development. Trends Cogn Sci. 2015;19(10):558-66. https://doi.org/10.1016/j.tics.2015.07.008

4. Bentham J, Di Cesare M, Bilano V, Bixby H, Zhou B, Stevens GA, et al. Worldwide trends in body-mass index, underweight, overweight, and obesity from 1975 to 2016: a pooled analysis of 2416 population-based measurement studies in 128.9 million children, adolescents, and adults. Lancet. 2017;390(10113):2627-42. https:doi.org/10.1016/ S0140-6736(17)32129-3

5. Aiello AM, Mello LM, Nunes MS, Silva AS, Nunes A. Prevalence of obesity in children and adolescents in Brazil: a meta-analysis of cross-sectional studies. Curr Pediatr Rev. 2015;11(1):36-42. https://doi.org/10.2174/157333963116 66150501003250

6. Bloch KV, Szklo M, Kuschnir MCC, Abreu GA, Barufaldi LA, Klein $\mathrm{CH}$, et al. The study of cardiovascular risk in adolescents ERICA: rationale, design and sample characteristics of a national survey examining cardiovascular risk factor profile in Brazilian adolescents. Bmc Public Health. 2015;15(1):1-10. https://doi.org/10.1186/s12889-015$1442-x$

7. Kolotkin RL, Meter K, Williams GR. Quality of life and obesity. Obes Rev. 2001;2(4):219-29. https://doi.org/10.1046/ j.1467-789X.2001.00040.x

8. Ferster CB, Nurnberger JI, Levtit EB. The control of eating. Obes Res. 1996;4(4):401-10. https://doi.org/10.10 02/9780470712221.ch6

9. Pedersen $A M L$, Sørensen $C E$, Proctor GB, Carpenter GH. Salivary functions in mastication, taste and textural perception, swallowing and initial digestion. Oral Dis. 2018;24(8):1399-416. https://doi.org/10.1111/odi.12867

10. Lasschuijt MP, Mars M, Graaf C, Smeets PAM. Exacting responses: lack of endocrine cephalic phase responses upon oro-sensory exposure. Front Endocrinol (Lausanne). 2018;13(9):322. https://doi.org/10.3389/fendo.2018.00332

11. Sakata T, Yoshimatsu H, Masaki T, Tsuda K. Anti-obesity actions of mastication driven by histamine neurons in rats. Exp Biol Med. 2003;228(10):1106-10. https://doi.org/10.1177/153537020322801002

12. Sakata T. Histamine receptor and its regulation of energy metabolism. Obes Res. 1995;3(4):541-8. https://doi. org/10.1002/j.1550-8528.1995.tb00225.x

13. Soares ME, Ramos-Jorge ML, Alencar BM, Oliveira SG, Pereira LJ, Ramos-Jorge J. Influence of masticatory function, dental caries and socioeconomic status on the body mass index of preschool children. Arch Oral Biol. 2017;81:69-73. https://doi.org/10.1016/j.archoralbio.2017.04.032

14. Sato N, Yoshiike N. Factors associated with the masticatory behavior of children assessed by the number of chews for a test meal of usual school lunch menu. Japanese J Nutr Diet. 2010;68(4):253-62. https://doi.org/10.5264/ eiyogakuzashi.68.253

15. Pedroni-Pereira A, Araujo DS, Scudine KGO, Prado DGA, Lima DANL, Castelo PM. Chewing in adolescents with overweight and obesity: an exploratory study with behavioral approach. Appetite. 2016;107:527-33. https://doi. org/10.1016/j.appet.2016.08.122

16. Hollis JH. The effect of mastication on food intake, satiety and body weight. Physiol Behav. 2018;193:242-5. https:// doi.org/10.1016/j.physbeh.2018.04.027

17. Moher D, Liberati A, Tetzlaff J, Altman DG. Preferred reporting items for systematic reviews and meta-analyses: the PRISMA statement. J Clin Epidemiol. 2009;62(10):1006-12. https://doi.org/10.1016/j.jclinepi.2009.06.005

18. West S, King V, Carey TS, Lohr KN, McKoy N, Sutton SF, et al. Systems to rate the strength of scientific evidence. Evid Rep Technol Assess (Summ). 2002;(47):1-11.

19. Berlese DB, Copetti F, Weimmann ARM, Ferreira PF, Haefffner LSB. Myofunctional characteristics and electromyographic of obese children and adolescents. Rev Cefac. 2013;15(4):913-21. https://doi.org/10.1590/ S1516-18462013000400020

20. Souza NC, Guedes ZCF. Mastigação e deglutição de crianças e adolescentes obesos. Rev Cefac. 2016;18(6):1340-7. https://doi.org/10.1590/1982-0216201618617015

21. Landis JR, Koch GG. The measurement of observer agreement for categorical data. Biometrics. 1977;33(1):159-74. https://doi.org/10.2307/2529310

22. Araujo DS, Marquezin MCS, Barbosa TDS, Gavião MBD, Castelo PM. Evaluation of masticatory parameters in overweight and obese children. Eur J Orthod. 2016;38(4):393-7. https://doi.org/10.1093/ejo/cjv092 
23. Soares ME, Ramos-Jorge ML, Alencar BM, Marques LS, Pereira LJ, Ramos-Jorge J. Factors associated with masticatory performance among preschool children. Clin Oral Investig. 2017;21(1):159-66. https://doi.org/10.1007/s00784016-1768-5

24. Sun KT, Chen SC, Li YF, Chiang HH, Tsai HH, Li CY, et al. Bite-force difference among obese adolescents in central Taiwan. J Formos Med Assoc. 2016;115(6):404-10. https://doi.org/10.1016/j.jfma.2015.05.007

25. De Morais Tureli MC, De Souza Barbosa T, Gavião MBD. Associations of masticatory performance with body and dental variables in children. Pediatr Dent. 2010;32(4):283-8.

26. Friedlander AH, Tajima T, Kawakami KT, Wang MB, Tomlinson J. The relationship between measures of nutritional status and masticatory function in untreated patients with head and neck cancer. J Oral Maxillofac Surg. 2008;66(1):85-92. https://doi.org/10.1016/j.joms.2007.08.023

27. Bolhuis DP, Forde CG, Cheng Y, Xu H, Martin N, De Graaf C. Slow food: sustained impact of harder foods on the reduction in energy intake over the course of the day. Plos One. 2014;2(9):e93370. https://doi.org/10.1371/journal. pone.0093370

28. Van Der Bilt A, Tekamp A, Van Der Glas H, Abbink J. Bite force and electromyograpy during maximum unilateral and bilateral clenching. Eur J Oral Sci. 2008;116(3):217-22. https://doi.org/10.1111/j.1600-0722.2008.00531.x

29. Roldán SI, Restrepo LG, Isaza JF, Vélez LG, Buschang PH. Are maximum bite forces of subjects 7 to 17 years of age related to malocclusion? Angle Orthod. 2016;86(3):456-61. https://doi.org/10.2319/051315-323.1

30. Su CM, Yang YH, Hsieh TY. Relationship between oral status and maximum bite force in preschool children. J Dent Sci. 2009;4(1):32-9. https://doi.org/10.1016/S1991-7902(09)60006-4

31. Giorelli P, Giorelli P, Filho DR. Distúrbios do sono: causa ou consequência da obesidade? Int J Nutrology. 2012;5(3):101-2.

32. Fukuda H, Saito T, Mizuta M, Moromugi S, Ishimatsu T, Nishikado S, et al. Chewing number is related to incremental increases in body weight from 20 years of age in Japanese middle-aged adults. Gerodontology. 2013;30(3):214-9. https://doi.org/10.1111/j.1741-2358.2012.00666.x

33. Andrade AM, Greene GW, Melanson KJ. Eating slowly led to decreases in energy intake within meals in healthy women. J Am Diet Assoc. 2008;108(7):1186-91. https://doi.org/10.1016/j.jada.2008.04.026

34. Felício CM, Melchior MO, Silva MAMR. Effects of orofacial myofunctional therapy on temporomandibular disorders. J Craniomandib Pract. 2010;28(4):249-59. https://doi.org/10.1179/crn.2010.033

35. Stróżyk P, Bałchanowski J. Modelling of the forces acting on the human stomatognathic system during dynamic symmetric incisal biting of foodstuffs. J Biomech. 2018;5(79):58-66. https://doi.org/10.1179/crn.2010.033

36. Van der Bilt A, Engelen L, Pereira LJ, Van der Glas HW, Abbink JH. Oral physiology and mastication. Physiol Behav. 2006;89(1):22-7. https://doi.org/10.1016/j.physbeh.2006.01.025

37. Pal I, Ghosh B, Ramachandra S. A brief description about the evolution of the masticatory complex, its causes and future effects: a review. J Orofac Sci. 2017;9(2):75-9. https://doi.org/10.4103/jofs.jofs_125_16

38. Liu D, Deng Y, Sha L, Abul Hashem M, Gai S. Impact of oral processing on texture attributes and taste perception. J Food Sci Technol. 2017;54(8):2585-93. https://doi.org/10.1007/s13197-017-2661-1

39. Gambareli FR, Serra MD, Pereira LJ, Gavião MBD. Teeth and muscle force interactions in. J Texture Stud. 2007;38(2007):2-20. https://doi.org/10.1111/j.1745-4603.2007.00083.x

40. Van der Bilt A, Abbink JH. The influence of food consistency on chewing rate and muscular work. Arch Oral Biol. 2017;83:105-10. https://doi.org/10.1016/j.archoralbio.2017.07.011

41. Pereira LJ, Duarte Gaviao MB, Van Der Bilt A. Influence of oral characteristics and food products on masticatory function. Acta Odontol Scand. 2006;64(4):193-201. https://doi.org/10.1080/00016350600703459

42. Cambraia RPB. Aspectos psicobiológicos do comportamento alimentar. Rev Nutr. 2004;17(2):217-25. https://doi. org/10.1590/S1415-52732004000200008 